\title{
Effects of Pinus densiflora on soil chemical and microbial properties in Pb-contaminated forest soil
}

\author{
Sunghyun Kim ${ }^{1}$, Insook Lee ${ }^{2}$ and Hojeong Kang ${ }^{1, *}$ \\ ${ }^{1}$ School of Civil and Environmental Engineering, Yonsei University, Seoul 120-749, Korea \\ ${ }^{2}$ Division of EcoScience, Ewha Womans University, Seoul 120-750, Korea
}

\begin{abstract}
We investigated the effect of $\mathrm{Pb}$ uptake by Pinus densiflora and the $\mathrm{Pb}$ fraction in forest soil. We also investigated the change in soil physicochemical characteristics, microbial activity, and root exudates of Pinus densiflora in Pb-contaminated soils. Three-year-old pine seedlings were exposed to $500 \mathrm{mg} / \mathrm{kg}$ Pb for $12 \mathrm{months}$. The metal fractions were measured using sequential extraction procedures. Additionally, factors that affect solubility (three soil enzyme activities and amino acids of root exudate compounds) were also determined. The results showed that $\mathrm{Pb}$ contamination significantly decreased enzyme activities due to soil characteristics. In addition, organic matter, nitrate content, and $\mathrm{Pb}$ concentration were time dependent. The results indicate that changes in the $\mathrm{Pb}$ fraction affected $\mathrm{Pb}$ uptake by pine trees due to an increase in the exchangeable $\mathrm{Pb}$ fraction. The concentrations of organic acids were higher in $\mathrm{Pb}$-spiked soil than those in control soil. Higher rhizosphere concentrations of oxalic acid resulted in increased $\mathrm{Pb}$ uptake from the soil. These results suggest that pine trees can change soil properties using root exudates due to differences in the metal fraction.
\end{abstract}

Key words: enzyme activity, $\mathrm{Pb}$ contaminated soils, $\mathrm{Pb}$ fraction, Pinus densiflora

\section{INTRODUCTION}

In Korea, base metal mines producing $\mathrm{Cu}-\mathrm{Pb}-\mathrm{Zn}$ ores are distributed almost over all of the country and were actively operated until the early 1980s. However, since then, base metal production has declined and most mines closed mainly due to economic reasons (Lee and Lee 2001). Upon closing of the mines, improperly disposed of mineral waste piles and untreated mine drainage have become important sources of heavy metals in the environment. In particular, lead $(\mathrm{Pb})$ contamination increased substantially with industrialization of the forest (Shotyk et al. 1998). Forest ecosystems are particularly sensitive to $\mathrm{Pb}$ pollution from atmospheric deposition, as their canopies have a high capacity to intercept aerosols, which are either washed down by rain or reach the soil through litter fall (Bringmark et al. 1998, Ettler et al. 2005). This explains why forests often contain high $\mathrm{Pb}$ concentrations in their topsoils. Due to its toxicity, $\mathrm{Pb}$ can have a strong adverse impact on soil microorganisms, and their nutrient cycle functions (Nannipieri et al. 2003). Heavy metal stress generally induces soil microbial communities to employ more energy to maintain metabolic functions and detoxification processes, thereby permitting less energy expenditure for growth. Pb stress has also been reported to reduce plant biomass, respiration rates, and enzymatic activities (Frey et al. 2006).

Heavy metal-contaminated forest soil is recycled using

\section{Open Access http://dx.doi.org/10.5141/JEFB.2011.034}

This is an Open Access article distributed under the terms of the Creative Commons Attribution Non-Commercial License (http://creativecommons. org/licenses/by-nc/3.0/) which permits unrestricted non-commercial use distribution, and reproduction in any medium, provided the original work is properly cited.
Received 21 June 2011, Accepted 08 July 2011

*Corresponding Author

E-mail: hj_kang@yonsei.ac.kr Tel: +82-2-2123-5803 
organic matter and native woody plants for remediation. Enzymatic activities are frequently used for determining the influence of heavy metal pollutants on soil microbiological quality (Shen et al. 2005). Heavy metals inhibit enzymatic activity by interacting with the enzyme substrate complexes and denaturing the enzyme protein (Vig et al. 2003). Therefore, soil microbial activities are important to understand the mechanisms and changes in forest ecosystems following metal contamination.

However, total concentrations alone may not convey the entire picture of metal reactivity and its potential toxicity to soil biota. Although the solubility of $\mathrm{Pb}$ is generally very low, a considerable fraction of total $\mathrm{Pb}$ in soil can exist in soluble forms (Wang and Benoit 1996). The behavior of metals and their availability strictly depends on their chemical form and, thus, on their speciation. Therefore, determining chemical form factors or associations with different mineral phases is of great importance to better understand $\mathrm{Pb}$ toxicity in forest soils. An estimate of metal availability is more valuable, as it is related to specific bioavailability, reactivity, mobility, and uptake by plants (McBride 1994). To date, it has generally been accepted that the most appropriate methods for evaluating solid speciation are selective sequential extraction procedures. In fact, a large number of sequential extraction methods have been studied and reported, many of which are variants of the Tessier procedure (Tessier et al. 1979). The mechanisms of metal accumulation in soil lead to five major geochemical forms: (i) exchangeable, (ii) bound to the carbonate phase; (iii) bound to ironmanganese oxides; (iv) bound to organic matter; and (v) a residual metal phase. These metal fractions exhibit remarkable differences in mobility, biological availability and chemical behavior in soil.

Dissolvability, adsorption, and the fraction of heavy metals in soils relate to low molecular weight root exudates, such as organic and amino acids (Kuang et al. 2003). McGrath et al. (1997) reported that $\mathrm{Zn}$ bioavailability in soil increases as a result of root exudates. Mench and Fargues (1994) found that the root exudates released from Avena sativa $\mathrm{L}$. increase the bioavailability of soil $\mathrm{Zn}, \mathrm{Cu}$, and $\mathrm{Ni}$ by dissolving ferriferous oxides. Additionally, Kim et al. (2010) reported that the bioavailable metal fraction in soils increased with the addition of root exudates. However, understanding the mechanism controlling nutrient availability in soil requires a comprehensive knowledge of the qualitative and quantitative composition of root exudates (Schilling et al. 1998).

The pine tree has been widely studied as a bio-indicator for measuring heavy metal toxicity (Pöykiö and Tor- vera 2001, Yilmaz 2002). Because pine trees are one of the dominant trees species in eastern Asia, we believe that information on the effects of $\mathrm{Pb}$ on pine trees is highly valuable. We report here on the impact of $\mathrm{Pb}$ contamination on accumulation and root exudates of Pinus densiflora, emphasizing the interdependency of soil chemistry and microbiology.

The purpose of this study was to investigate the toxicity of $P$. densiflora, soil properties, and soil microorganisms in a forest. We also investigated changes in Pb bioavailability that might affect the microbial activity and root exudates of $P$. densiflora.

\section{MATERIALS AND METHODS}

\section{Experimental design}

Natural soil was sampled from the campus of Ewha Woman's University, which is located in Seoul, Korea. We collected surface soils from a pine tree (Pinus koraiensis $S$. et $Z$.) dominant forest. The physicochemical properties of the soil are shown in Table 1. The soil was passed through a $2 \mathrm{~mm}$ sieve and then air-dried. For each experiment, $32 \mathrm{~kg}$ soil aliquots were artificially contaminated with $500 \mathrm{mg} / \mathrm{kg} \mathrm{Pb}$, added as an aqueous solution of $\mathrm{PbSO}_{4}$. The soils were then thoroughly mixed to ensure uniformity and then aged 1 week to stabilize. Contaminated soils were measured $24 \mathrm{~h}$ prior to the start of each test. Soils were divided into two groups (uncontaminated soils and contaminated soils) in a total of 32 pots. Three-year old pine seedlings (P. densiflora), which were obtained from the Korean Forest Service, were planted in both uncontaminated soils and $\mathrm{Pb}$-contaminated soils in $1 \mathrm{~kg}$ test pots $(1.5 \mathrm{~L}$ cylindrical plastic pots; diameter, $10 \mathrm{~cm}$ ). Thirty $\mathrm{mL}$ of water and $20 \mathrm{~mL}$ of $1 / 2$ Hoagland solution (Hoagland and Arnon 1950) were added to the soil weekly. The plants were incubated for 12 months in a greenhouse. Every 4 months, the shoots, roots, and soil in each pot were harvested. After the harvest, plants were washed with water to remove soil particles. To determine the amount of $\mathrm{Pb}$ in the plants, the roots and shoots were further separated with scissors and then dried in an oven at $70^{\circ} \mathrm{C}$ for $24-\mathrm{h}$. Plants samples were digested in concentrated $\mathrm{HNO}_{3}$ in an automatic microwave digester (MDS-2000; CEM, Matthews, NC, USA) and allowed to digest for 1-h at full power $(630 \mathrm{w})$. Pb content was then determined with an atomic absorption spectrometer 100 graphite-furnace (AAS analysis 100; Perkin Elmer, Kundenunterstützung, Germany). 
For quality control, a certified reference sample of total metal content in plants was analyzed using the methods described above. Observed concentrations for the certified SRM 1575 (pine needles; National Institute of Standards Technology) were measured. The percentage recovery for the metal of interest was $92.6 \%$.

\section{Soil characteristics and enzyme activities}

Soil $\mathrm{pH}$ was determined by adding soil to water at a ratio of 1:5 (w:v). Soil organic matter content was determined by loss-on-ignition at $700^{\circ} \mathrm{C}$ in a furnace (MAS 7000; CEM) (Saxena and Bartha, 1983). Soil cationexchange capacity (CEC) was determined by EPA 9081 methods (US Environmental Protection Agency 1986). Soil nitrate $\left(\mathrm{NO}_{3}^{-}\right)$content was determined by extracting soil with deionized water and then measuring $\mathrm{NO}_{3}{ }^{-}$content in the liquid phase using an $\mathrm{NO}_{3}{ }^{-}$electrode (Gelderman and Beegle 1998).

Dehydrogenase activity was measured with an was 2-[4-iodophenyl]-3-[4-nitrophenyl]-5-phenyltetrazolium chloride assay (Tabatabai 1982). The mixtures (fresh soil 3 g) were incubated for $2-\mathrm{h}$ at $37^{\circ} \mathrm{C}$. Reaction products were detected using a spectrophotometer (DR/3000 Spectrophotometer; HACH, Loveland, CO, USA) at $485 \mathrm{~nm}$.

The activities of $\beta$-glucosidase and acid phosphatase were measured using the methylumbelliferone (MUF)substrate method (Freeman et al. 1996). The concentration of the MUF- $\beta$-glucoside substrate solution was 400 $\mu \mathrm{M}$ (Sigma, St. Louis, MO, USA), whereas the concentration of the MUF-phosphate substrate solution was 800 $\mu \mathrm{M}$ (Sigma). The enzymatic activities in the soil and substrate solution $(1: 5, \mathrm{w} / \mathrm{v})$ were measured using a fluorometer.

\section{Sequential soil extraction procedures}

To determine the amount of $\mathrm{Pb}$ in the soils, $\mathrm{Pb}$ was fractionated by the sequential extraction procedure of Tessier et al. (1979) in triplicate. Extractions were conducted in $50 \mathrm{~mL}$ polypropylene centrifuge tubes. Between each extraction, the supernatant was centrifuged at 6,000 rpm for $15 \mathrm{~min}$ and filtered. The five fraction methods indicated below used $1 \mathrm{~g}$ of dry soil.

(i) Exchangeable: The soil was extracted at room temperature for 1-h with $8 \mathrm{~mL}$ of magnesium chloride solution (1M $\mathrm{MgCl}_{2}, \mathrm{pH} 7.0$ );

(ii) Bound to the carbonate phase: The residue from (i) was leached at room temperature with $8 \mathrm{~mL}$ of $1 \mathrm{M}$ $\mathrm{NaOAc}$ adjusted to a pH of 5.0 with acetic acid (HOAc). Continuous agitation was maintained, and the time necessary for complete extraction was evaluated;

(iii) Bound to iron-manganese oxides: The residue from (ii) was extracted with $20 \mathrm{~mL} 0.4 \mathrm{M} \mathrm{NH}_{2} \mathrm{OH} \mathrm{HCl}$ in $25 \%$ (v/v) HOAc. The latter experiments were performed at 96 $\pm 3^{\circ} \mathrm{C}$ with occasional agitation, and the time needed for complete dissolution of the free iron oxides was evaluated;

(iv) Bound to organic matter: To the residue from (iii), 3 $\mathrm{mL}$ of $0.02 \mathrm{M} \mathrm{HNO}_{3}$ and $5 \mathrm{~mL}$ of $30 \% \mathrm{H}_{2} \mathrm{O}_{2}$ were added and adjusted to a $\mathrm{pH}$ of 2 with $\mathrm{HNO}_{3}$, and the mixture was heated to $85 \pm 2^{\circ} \mathrm{C}$ for 2 -h with occasional agitation.

A second $3 \mathrm{~mL}$ aliquot of $30 \%$ (v) residual metal phase: The residue from (iv) was digested with a $\mathrm{HF}-\mathrm{HClO}_{4}$ mixture according to the procedure described below for total metal analysis.

(vi) Total: Fresh sample (1.0 g) was digested with $8 \mathrm{~mL}$ of aqua regia $\left(\mathrm{HCl}\right.$ and $\left.\mathrm{HNO}_{3}, 3+1, \mathrm{v} / \mathrm{v}\right)$ for $2-\mathrm{h}$ at $120^{\circ} \mathrm{C}$.

To verify the reliability of our sequential extraction

Table 1. Soil physicochemical characteristics

\begin{tabular}{lccccc}
\hline & Treatment & Initial & 4 months & 8 months & 12 months \\
\hline $\mathrm{pH}(1: 5)$ & Control & $5.6 \pm 0.4$ & $5.6 \pm 0.4$ & $5.5 \pm 0.01$ & $5.3 \pm 0.03$ \\
& $\mathrm{~Pb}$ & $4.8 \pm 0.2$ & $4.8 \pm 0.2$ & $4.9 \pm 0.1$ & $5.0 \pm 0.1$ \\
Moisture content & Control & $10.0 \pm 2.5$ & $10.4 \pm 1.2$ & $10.5 \pm 1.3$ & $9.2 \pm 0.3$ \\
(g/kg) & $\mathrm{Pb}$ & $10.2 \pm 2.3$ & $10.2 \pm 1.5$ & $12.7 \pm 0.5^{*}$ & $13.4 \pm 1.0^{*}$ \\
Organic matter & $\mathrm{Control}$ & $2.6 \pm 0.2$ & $2.8 \pm 0.7$ & $2.9 \pm 0.02$ & $3.5 \pm 0.01$ \\
(g/kg) & $\mathrm{Pb}$ & $2.8 \pm 0.2$ & $4.0 \pm 0.2^{* *}$ & $3.9 \pm 0.1^{*}$ & $4.0 \pm 0.4^{*}$ \\
$\mathrm{CEC}$ & $\mathrm{Control}$ & $10.3 \pm 0.3$ & $11.9 \pm 1.6$ & $10.8 \pm 0.4$ & $9.9 \pm 0.2$ \\
$(\mathrm{cmol} / \mathrm{kg})$ & $\mathrm{Pb}$ & $10.2 \pm 0.04$ & $11.1 \pm 1.9$ & $12.5 \pm 0.1^{*}$ & $12.5 \pm 0.5^{* *}$ \\
Nitrate & $\mathrm{Control}$ & $12.0 \pm 0.5$ & $15.0 \pm 2.0$ & $17.0 \pm 3.0$ & $18.7 \pm 3.0$ \\
$(\mathrm{mg} / \mathrm{kg})$ & $\mathrm{Pb}$ & $12.0 \pm 0.5$ & $11.1 \pm 1.9$ & $12.5 \pm 0.1^{*}$ & $12.5 \pm 0.5^{* *}$ \\
\hline
\end{tabular}

Values represent means of three replicates.

Significant after $t$-test at ${ }^{* *} P<0.05,{ }^{* *} P<0.01,{ }^{* * *} P<0.001$ (vs. control group).

CEC, cation exchange capacity. 
procedures, recovery (\%) of the sum of the $\mathrm{Pb}$ concentrations in individual fractions to the total $\mathrm{Pb}$ concentration in soils was calculated and found to be $102.5 \%$.

\section{Analysis of root exudates}

Plants were harvested by gently removing them from the soil. Prior to analysis, the plants were washed with water to remove soil particles. The plants were sampled and the extracts were prepared as described by Yun and Kil (1992). Fresh roots (100 g) were immersed in $1 \mathrm{~L}$ of distilled water for 48 -h, after which the solutions were filtered through a $0.45 \mu \mathrm{m}$ syringe filter and used undiluted.

Organic acids were analyzed with an ion chromatography unit (DX-500; Dionex, Sunnyvale, CA, USA) equipped with an ED40 electro-chemical detector, an IonPac AS11 $(4 \times 250 \mathrm{~mm})$ column, and an ASRS-Ultra II Anion selfregenerating suppressor (CA). The total concentration of the root organic acids was calculated as the sum of the concentrations of individual organic acids.

\section{Statistical analysis}

We used a repeated-measures analysis of variance (ANOVA) to determine the effects of time and $\mathrm{Pb}$ treatment on the physical and chemical characteristics of the soil and on soil enzyme activity using SPSS ver. 17.0 (SPSS Inc., Chicago, IL, USA). The relationship between metal uptake and the metal fraction was determined using a classic multivariate linear regression model on Microsoft Excel.

\section{RESULTS}

\section{Soil characteristics and enzyme activity}

The soil characteristics are shown in Table 1. The physicochemical properties of the soil were as follows: Soil texture, loamy sand $(54.1 \%$ sand, $30.9 \%$ silt, and $15.0 \%$ clay); total organic matter, $2.8 \%$; total moisture content, $10 \%$; CEC, $10.3 \mathrm{mmol} / \mathrm{kg}$. Soil $\mathrm{pH}$ was in the weakly acidic range (5.6-6.2).

Table 2 describes the soil enzyme activity. Dehydrogenase, acid phosphatase, and $\beta$-glucosidase decreased

Table 2. Comparison of enzyme activities in rhizosphere soils

\begin{tabular}{cccccc}
\hline & Treatment & Initial & 4 months & 8 months & 12 months \\
\hline Dehydrogenase & Control & $52.7 \pm 2.9$ & $55.2 \pm 4.6$ & $66.7 \pm 3.1$ & $70.5 \pm 5.9$ \\
& $\mathrm{~Pb}$ & $36.7 \pm 3.7$ & $45.2 \pm 3.5$ & $47.7 \pm 4.6$ & $47.7 \pm 4.6$ \\
Acid & $\mathrm{Control}$ & $213.6 \pm 13.4$ & $178.4 \pm 17.4$ & $168.9 \pm 8.8$ & $148.8 \pm 7.9$ \\
phosphatase & $\mathrm{Pb}$ & $202 \pm 12.4$ & $140 \pm 12.9^{*}$ & $129.4 \pm 9.3^{*}$ & $101 \pm 15.1^{*}$ \\
& $\mathrm{Control}$ & $40.0 \pm 4.0$ & $45.0 \pm 2.5$ & $53.0 \pm 5.8$ & $60.0 \pm 7.5$ \\
$\beta$-glucosidase & $\mathrm{Pb}$ & $38.5 \pm 4.0$ & $41.2 \pm 1.5$ & $43.0 \pm 2.2^{*}$ & $51.4 \pm 3.0^{*}$ \\
\hline
\end{tabular}

Values represent means of three replicates.

Significant after $t$-test at ${ }^{*} P<0.05,{ }^{* *} P<0.01,{ }^{* * * *} P<0.001$ (vs. control group).

Table 3. Repeated measures analysis of variance (ANOVA) for Pb treatments with increasing time

\begin{tabular}{|c|c|c|c|c|c|c|c|c|c|}
\hline \multirow[b]{3}{*}{ Variable } & \multicolumn{9}{|c|}{ Repeated measures ANOVA } \\
\hline & \multicolumn{3}{|c|}{$\mathrm{Pb}$} & \multicolumn{3}{|c|}{ Time } & \multicolumn{3}{|c|}{$\mathrm{Pb} \times$ time } \\
\hline & df & $F$ & $P$ & df & $F$ & $P$ & df & $F$ & $P$ \\
\hline $\mathrm{pH}$ & 1 & 36.615 & 0.004 & 3 & 0.234 & 0.871 & 3 & 1.892 & 0.185 \\
\hline MC & 1 & 36.615 & 0.131 & 3 & 2.069 & 0.158 & 3 & 3.823 & 0.039 \\
\hline $\mathrm{OM}$ & 1 & 94.051 & 0.001 & 3 & 11.83 & 0.01 & 3 & 3.57 & 0.047 \\
\hline CEC & 1 & 4.5 & 0.101 & 3 & 3.391 & 0.054 & 3 & 5.257 & 0.015 \\
\hline Nitrate & 1 & 82.094 & 0.001 & 3 & 11.95 & 0.001 & 3 & 7.932 & 0.004 \\
\hline DHA & 1 & 212.6 & 0.00 & 3 & 97.6 & 0.00 & 3 & 16.8 & 0.000 \\
\hline APA & 1 & 7,062 & 0.002 & 3 & 43.08 & 0.00 & 3 & 2.192 & 0.142 \\
\hline BGO & 1 & 57.0 & 0.002 & 3 & 43.08 & 0.00 & 3 & 2.192 & 0.142 \\
\hline
\end{tabular}

Variables include the physicochemical characteristics and soil enzyme activities (dehydrogenase, acid phosphatase, and $\beta$-glucosidase).

MC, moisture content; OM, organic matter; CEC, cation exchange capacity; DHA, dehydrogenase; APA, acid phosphatase; BGO, $\beta$-glucosidase. 
remarkably with increasing $\mathrm{Pb}(P<0.01)$ (Table 2). Relative to the controls, dehydrogenase, acid phosphatase, and $\beta$-glucosidase activity in the $\mathrm{Pb}$ treatment group decreased $33 \%, 32 \%$, and $12 \%$, respectively. However, in $\mathrm{Pb}$ contaminated soils, dehydrogenase and $\beta$-glucosidase increased with time. In contrast, acid phosphatase activity decreased slightly over the same time period.

The $\mathrm{pH}$ decreased slightly in $\mathrm{Pb}$-contaminated soils due to the use of the $\mathrm{PbSO}_{4}$ solution, although it did not significantly change over time. Organic matter and nitrate were greatly influenced by both $\mathrm{Pb}$ and time. Additionally, there were $\mathrm{Pb}-\mathrm{X}$ time interactions, as indicated by the repeated-measures ANOVA (Table 3). Organic matter increased with time and $\mathrm{Pb}$ treatment. Nitrate decreased with $\mathrm{Pb}$ treatment but increased with time.

\section{Changes in the soil $\mathrm{Pb}$ fraction and uptake by Pinus densiflora}

The soil $\mathrm{Pb}$ binding forms are presented in Fig. 1. Most of the $\mathrm{Pb}$ soil fraction was bound to iron-manganese oxides. The percentage present as exchangeable (F1) and $\mathrm{Pb}$-bound to carbonate (F2) fractions and bioavailability decreased over time, although the F3 and F4 fractions increased over time. The amount of $\mathrm{Pb}$ bound to $\mathrm{Fe}-\mathrm{Mn}$ oxides (F3) and bound to organic matter (F4) increased consistently with increasing incubation time. After 8 months of incubation, the $\mathrm{Pb}$ concentration in the $\mathrm{Fe}$ $\mathrm{Mn}$ oxide-bound fraction in soil reached $358 \mathrm{mg} / \mathrm{kg}$. $\mathrm{Pb}$ concentrations were $62 \mathrm{mg} / \mathrm{kg}$ in the organic matter fraction.

Fig. 2 shows the correlations between soil exchangeable $\mathrm{Pb}$ concentrations and pine tree uptake of $\mathrm{Pb} . \mathrm{Pb}$ uptake by roots and shoots was positively correlated to an increase in exchangeable $\mathrm{Pb}$ in the soil. Absorption and accumulation of $\mathrm{Pb}$ in the roots and shoots increased with time. The $\mathrm{Pb}$ content bound to roots increased to nearly $90 \%$ upon exposure to $\mathrm{Pb}$.

\section{Organic acids in root exudates}

Table 4 shows the organic acid concentrations of pine root exudates, which affected growth rate and heavy metal uptake. The primary organic acid in the pine exudates was succinic acid. Furthermore, small amounts of oxalic acid, acetic acid, and citric acid were detected in root exudates. Specifically, the amount of oxalic acid was 4-fold greater in the roots of pine in the pots treated with $\mathrm{Pb}$ after 12 months, although succinic acid decreased during the incubation period. Acetic acid was only detected in

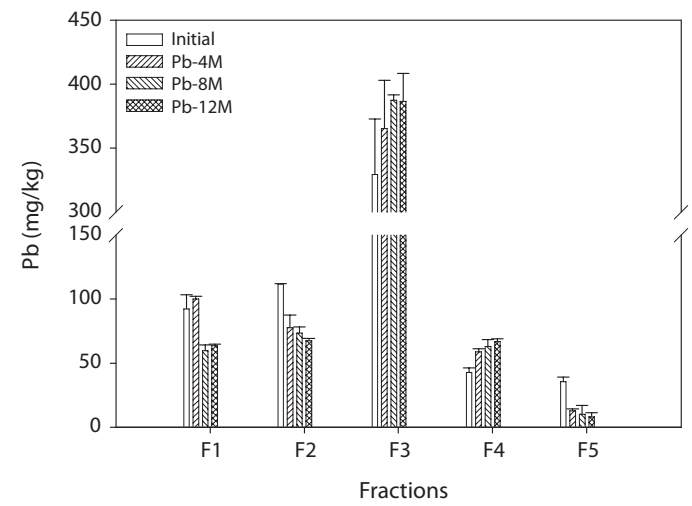

Fig. 1. The concentration of soil $\mathrm{Pb}$ in fractions using a sequential extraction procedure. $F 1$, exchangeable; $F 2$, bound to carbonates; $F 3$, bound to Fe-Mn oxides; $F 4$, bound to organic matter; $F 5$, residual; $M$, months.
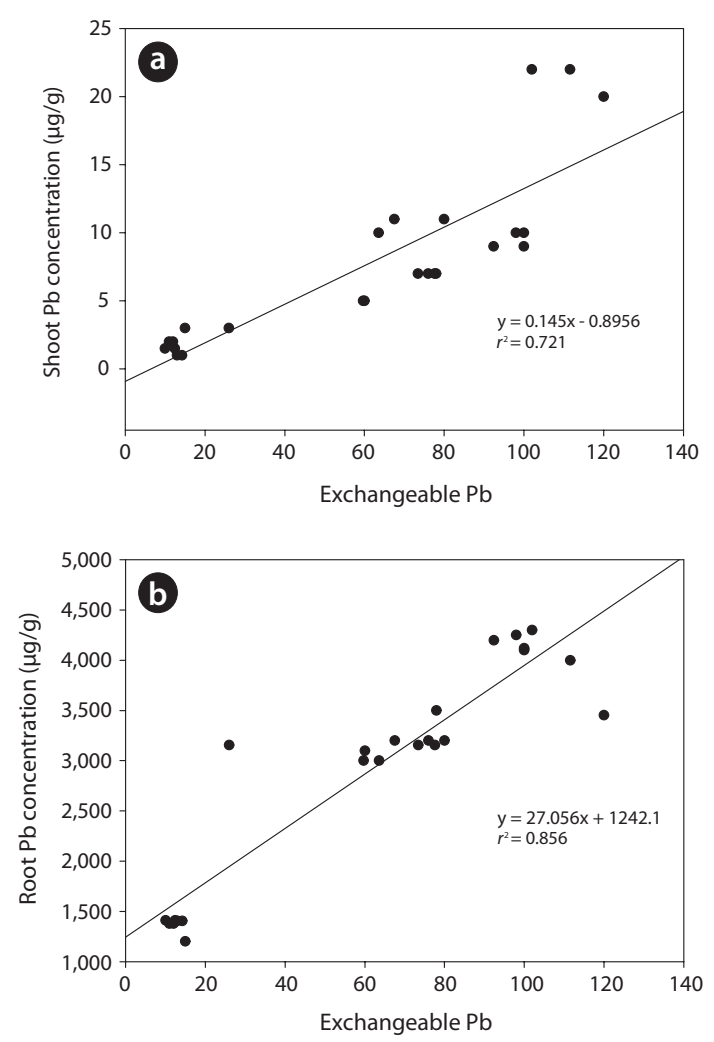

Fig. 2. Correlation between soil exchangeable $\mathrm{Pb}$ concentrations and shoot $\mathrm{Pb}$ concentration (a) and root $\mathrm{Pb}$ concentration (b).

Table 4. The concentrations $(\mu \mathrm{g} / \mathrm{g})$ of organic acids in pine root exudates

\begin{tabular}{llcccc}
\hline Treatment & $\begin{array}{c}\text { Succinic } \\
\text { acid }\end{array}$ & Oxalic acid & $\begin{array}{c}\text { Citric } \\
\text { acid }\end{array}$ & Acetic acid & $\begin{array}{c}\text { Total } \\
(\mu \mathrm{g} / \mathrm{g})\end{array}$ \\
\hline Control & 84.4 & 3.9 & 0.03 & $\mathrm{ND}$ & 88.3 \\
$\mathrm{~Pb}-4 \mathrm{M}$ & 80 & 4.2 & 0.01 & 2.8 & 87.0 \\
$\mathrm{~Pb}-8 \mathrm{M}$ & 79 & 5.0 & 0.01 & 2.5 & 86.5 \\
$\mathrm{~Pb}-12 \mathrm{M}$ & 76.5 & 12.0 & $\mathrm{ND}$ & 2.3 & 90.8 \\
\hline
\end{tabular}

$\mathrm{M}$, months; ND, not detectable. 
Pb-contaminated soils.

\section{DISCUSSION}

\section{Changes in soil characteristics and enzyme activity}

Enzyme activity significantly decreased in Pb-contaminated soils. Such a decrease in microbial activity was concomitant with a marked increase in exchangeable and soluble $\mathrm{Pb}$. Effects exerted on microbial activity may be attained by lowering the soil $\mathrm{pH}$ with organic acid (Shotyk et al. 1998), and complexation with heavy metals (Wierzbicka 1999), clay minerals and metal oxides with organic ligands from bacterial exudation (Gadd 2000). The effects of soil pollution on enzyme activity are complex; the response of different enzymes to the same pollutant may vary greatly, and the same enzyme may respond differently to different pollutants (He et al. 2003). In this study, $\mathrm{Pb}$ inhibited all enzyme activity, whereas $\mathrm{Pb}$ only slightly inhibited organic C-acquiring enzyme activity ( $\beta$-glucosidase). It has been reported that different metal ions exhibit different behavior in their ability to act as $\beta$-glucosidase inhibitors (Scigelova and Crout 1999).

However, dehydrogenase and $\beta$-glucosidase increased over time in the rhizosphere. Under the influence of root activity, $\mathrm{Pb}$ extracted from polluted soils increased, as $\mathrm{pH}$ decreased. Exchangeable $\mathrm{Pb}$ was much higher in the rhizosphere than that in bulk soil. Plants can modify metal speciation and behavior in the rhizosphere by producing exudates (Laperche et al. 1997), and these results were time dependent. The pine exudates may have been affected by an interaction with microbial activities and soil properties in the rhizosphere. Some researchers have studied the relationships between the pine rhizosphere and metal toxicity. Hartley-Whitaker et al. (2000) reported that $\mathrm{Cd}$ and $\mathrm{Zn}$ accumulation in P. sylvestris seedlings increases and reduces the effects of metal toxicity due to enhanced root microbes. The toxic effect of Scot pine seedlings is associated with their root fungi during multi metal contamination (Hartley et al. 1999). Also, a positive correlation exists between soil properties, such as cation exchange capacity and microbial processes under heavy metal stress (Bååth 1989).

\section{Correlation between soil exchangeable $\mathrm{Pb}$ and shoot and root $\mathrm{Pb}$ concentrations}

Fig. 1 shows the time-dependent changes in $\mathrm{Pb}$ concentration of each fraction. Cultivation time significantly affected the $\mathrm{Pb}$ fraction distribution. The newly added $\mathrm{Pb}$ existed mainly in the surface soil particles as an exchangeable fraction.

Fig. 2 presents the correlations between soil exchangeable $\mathrm{Pb}$ concentrations and pine tree uptake of $\mathrm{Pb}$. Exchangeable metals in the soil are easily available for plant uptake (Kabata-Pendias 1993). Metal toxicity and accumulation in plants are related to the effects of synergetic and antagonistic metal interactions. These effects may vary depending on the physicochemical factors such as organic matter content, $\mathrm{pH}$, redox potential, and ion speciation. These factors could influence metal mobility and bioavailability in soils (van Gestel 2008). For example, lower soil $\mathrm{pH}$ favors the release of metals into soil solution, allowing plants to take up more metals (Tang et al. 2003, Wu et al. 2009). In the present study, soil pH decreased slightly with the addition of $\mathrm{Pb}$ (Table 1). Moreover, a high organic matter content in soil resulted in increased organic matter in the bound fractions (F3 and F4) over time (Table 2). These results show that the metal fraction in soil was related to changes in the organic matter content due to microbial activity (Lock and Janssen 2001). Investigations relative to these questions should complement the present approach for a full understanding of the multifaceted issue of bioavailability in soil systems.

\section{Organic acids in root exudates}

An increase in $\mathrm{Pb}$ uptake was associated with increases in root exudates, suggesting that the root exudates activate $\mathrm{Pb}$ by dissolution and chelation. Because $\mathrm{pH}$ is a key factor controlling heavy metal extractability and mobility, changes in organic acids in root exudates may modify $\mathrm{Pb}$ availability by changing the $\mathrm{pH}$ (Zhang et al. 2006). Other studies have shown the significance of root exudates in the bioavailability of heavy metals in soil (Chen et al. 2006, Zhang et al. 2006). High molecular weight organic acids, such as humic acid, can reduce the bioavailability and toxicity of heavy metals (Liao and Huang 2002), whereas low molecular weight organic acids and amino acids can increase the bioavailability and plant accumulation of heavy metals by decreasing the rhizosphere $\mathrm{pH}$ or chelating metals in the soil (Liao and Huang 2002).

The results of this study demonstrate that changes in the soil metal fraction are related to soil chemical characteristics, microbial activity, and root exudates. The exchangeable metal content increased in soil with a low $\mathrm{pH}$ and the presence of organic acids from root exudates. In addition, root exudates change microbial activity that use 
the main C-sources: d-malic acid, d-glucosaminic acid, and $\alpha$-ketobutyric acid (data not shown). These findings indicate that organic acids from plant roots can combine with metal ions, which can then be taken up easily by microbes and plants.

\section{ACKNOWLEDGMENTS}

This study was conducted with the support of NRF (2010-0028708), Eco River 21, Eco Star, and AEBRC.

\section{LITERATURE CITED}

Bååth E. 1989. Effects of heavy metals in soil on microbial processes and populations. Water Air Soil Pollut 47: 335-379.

Bringmark L, Bringmark, E, Samuelsson B. 1998. Effects on mor layer respiration by small experimental additions of mercury and lead. Sci Total Environ 213: 115-119.

Chen RF, Shen RF, Gu P, Dong XY, Du CW, Ma JF. 2006. Response of rice (Oryza sativa) with root surface iron plaque under aluminium stress. Ann Bot 98: 389-395.

Ettler V, Vaněk A, Mihaljevic M, Bezdička P. 2005. Contrasting lead speciation in forest and tilled soils heavily polluted by lead metallurgy. Chemosphere 58: 1449-1459.

Freeman C, Liska G, Ostle NJ, Lock MA, Reynolds B, Hudson J. 1996. Microbial activity and enzymic decomposition processes following peatland water table drawdown. Plant Soil 180: 121-127.

Frey B, Stemmer M, Widmer F, Luster J, Sperisen C. 2006. Microbial activity and community structure of a soil after heavy metal contamination in a model forest ecosystem. Soil Biol Biochem 38: 1745-1756.

Gadd GM. 2000. Bioremedial potential of microbial mechanisms of metal mobilization and immobilization. Curr Opin Biotechnol 11: 271-279.

Gelderman RH, Beegle D. 1998. Nitrate-nitrogen. In: Recommended Chemical Soil Test Procedures for the North Central Region (Brown JR, ed). University of MissouriColumbia, Columbia, MO, pp 17-20.

Hartley J, Cairney JWG, Freestone P, Woods C, Meharg AA. 1999. The effects of multiple metal contamination on ectomycorrhizal Scots pine (Pinus sylvestris) seedlings. Environ Pollut 106: 413-424.

Hartley-Whitaker J, Cairney JWG, Meharg AA. 2000. Sensitivity to Cd or Zn of host and symbiont of ectomycorrhizal Pinus sylvestris L. (Scots pine) seedlings. Plant Soil 218: 31-42.
He ZL, Yang XE, Baligar VC, Calvert DV. 2003. Microbiological and biochemical indexing systems for assessing quality of acid soils. Adv Agron 78: 89-138.

Hoagland DR, Arnon DI. 1950. The Water Culture Method for Growing Plants without Soil. University of California, Agricultural Experiment Station, Berkley.

Kabata-Pendias A. 1993. Behavioural properties of trace metals in soils. Appl Geochem 8(Suppl 2): 3-9.

Kim S, Lim H, Lee I. 2010. Enhanced heavy metal phytoextraction by Echinochloa crus-galli using root exudates. J Biosci Bioeng 109: 47-50.

Kuang YW, Wen DZ, Zhong CW, Zhou GY. 2003. Root exudates and their roles in phytoremediation. Acta Phytoecol Sin 27: 709-717.

Laperche V, Logan, TJ, Gaddam P, Traina SJ. 1997. Effect of apatite amendments on plant uptake of lead from contaminated soil. Environ Sci Technol 31: 2745-2753.

Lee CH, Lee HK. 2001. Hydrochemical monitoring and heavy metal contaminations at the Narim Mine Creek in the Sulcheon District, Republic of Korea. Environ Geochem Health 23: 343-368.

Liao M, Huang C. 2002. Effects of organic acids on the toxicity of cadmium during ryegrass growth. Chin J Appl Ecol 13: 109-112.

Lock K, Janssen CR. 2001. Modeling zinc toxicity for terrestrial invertebrates. Environ Toxicol Chem 20: 1901-1908.

McBride MB. 1994. Environmental Chemistry of Soils. Oxford University Press, New York, pp 31-62.

McGrath SP, Shen ZG, Zhao FJ. 1997. Heavy metal uptake and chemical changes in the rhizosphere of Thlaspi caerulescens and Thlaspi ochroleucum growon in contaminated soils. Plant Soil 188: 153-159.

Mench MJ, Fargues S. 1994. Metal uptake by iron-efficient and inefficient oats. Plant Soil 165: 227-233.

Nannipieri P, Ascher J, Ceccherini MT, Landi L, Pietramellara G, Renella G. 2003. Microbial diversity and soil functions. Eur J Soil Sci 54: 655-670.

Pöykiö R, Torvera H. 2001. Pine needles (Pinus Sylvestris) as a bio-indicator of sulphur and heavy metal deposition in the area around a pulp and paper mill complex at Kemi, northern Finland. Int J Environ Anal Chem 79: 143-154.

Saxena A, Bartha R. 1983. Microbial mineralization of humic acid-3,4-dichloroaniline complexes. Soil Biol Biochem 15: 59-62.

Schilling G, Gransee A, Deubel A, Lezovic G, Ruppel S. 1998. Phosphorus availability, root exudates, and microbial activity in the rhizosphere. J Plant Nutr Soil Sci 161: 465478.

Scigelova M, Crout DHG. 1999. Microbial $\beta$ - $N$-acetylhexosaminidases and their biotechnological applications. 
Enzyme Microb Technol 25: 3-14.

Shen G, Lu Y, Zhou Q, Hong J. 2005. Interaction of polycyclic aromatic hydrocarbons and heavy metals on soil enzyme. Chemosphere 61: 1175-1182.

Shotyk W, Weiss D, Appleby PG, Cheburkin AK, Frei R, Gloor M, Kramers JD, Reese S, Van Der Knaap WO. 1998. History of atmospheric lead deposition since $12,370{ }^{14} \mathrm{C}$ yr BP from a Peat Bog, Jura Mountains, Switzerland. Science 281: 1635-1640.

Tabatabai MA. 1982. Soil enzymes. In: Methods of Soil Analysis, Part 2. Agronomy Monograph (Page AL, ed). American Society of Agronomy, Madison, WI, pp 903-904.

Tang S, Xi L, Zheng J, Li H. 2003. Response to elevated $\mathrm{CO}_{2}$ of Indian mustard and sunflower growing on copper contaminated soil. Bull Environ Contam Toxicol 71: 988-997.

Tessier A, Campbell PGC, Bisson M. 1979. Sequential extraction procedure for the speciation of particulate trace metals. Anal Chem 51: 844-851.

US Environmental Protection Agency. 1986. Test Methods for Evaluating Solid Waste. SW-846, Method 9081. US Environmental Protection Agency, Washington D.C., DC.

van Gestel CAM. 2008. Physico-chemical and biological pa- rameters determine metal bioavailability in soils. Sci Total Environ 406: 385-395.

Vig K, Megharaj M, Sethunathan N, Naidu R. 2003. Bioavailability and toxicity of cadmium to microorganisms and their activities in soil. Adv Environ Res 8: 121-135.

Wang EX, Benoit G. 1996. Mechanisms controlling the mobility of lead in the spodosols of a northern hardwood forest ecosystem. Environ Sci Technol 30: 2211-2219.

Wierzbicka M. 1999. Comparison of lead tolerance in Allium cepa with other plant species. Environ Pollut 104: 41-52.

Wu H, Tang S, Zhang X, Guo J, Song Z, Tian S, Smith DL. 2009. Using elevated $\mathrm{CO}_{2}$ to increase the biomass of a Sorghum vulgare $\times$ Sorghum vulgare var. sudanense hybrid and Trifolium pratense L. and to trigger hyperaccumulation of cesium. J Hazard Mater 170: 861-870.

Yilmaz S. 2002. Determination of optimal land use of Erzurum plain. Atatürk Üniv, Agric Fac 32: 485-498.

Yun KW, Kil BS. 1992. Assessment of allelopathic potential in Artemisia princeps var. orientalis residues. J Chem Ecol 18: 1933-1940.

Zhang MK, He ZL, Calvert DV, Stoffella PJ. 2006. Extractability and mobility of copper and zinc accumulated in sandy soils. Pedosphere 16: 43-49. 